\title{
WINA I WSTYD. ANALIZA LINGWISTYCZNA JAKO PROLOGEMENA DO NAUCZANIA KOŚCIOŁA KATOLICKIEGO Z ZAKRESU MORALNOŚCI
}

\section{WPROWADZENIE}

Świadomość winy i wstydu z powodu popełnionego zła towarzyszy ludzkości od początku dziejów. Czasami wstydzimy się swoich czynów, a sumienie wyrzuca nam poczucie winy. Należy zauważyć, że skoro nikt z ludzi nie jest bez grzechu', to każdego w jakimś stopniu dotyka przekonanie o jego winie i słabości. „Cóż mogę powiedzieć pełen wstydu i winy? (...) Zgrzeszyłem, Panie, zgrzeszyłem, zmiłuj się nade mną, odpuść mi. Daj mi trochę czasu, bym zdążył opłakać swój ból, nim odejdę do krainy ciemności osnutej mgłą śmierci. Cóż tak wielkiego żądasz od winowajcy i nieszczęsnego grzesznika? Tylko tego, aby wzbudził w sobie skruchę i ukorzył się z powodu swoich win"2.

Możemy mówić o winie moralnej ludzi, którzy we wzajemnej komunikacji krzywdzą innych przez nadużycie słowa. Wiadomo, że

\footnotetext{
1 Jedynie Maryja, matka Zbawiciela Jezusa Chrystusa została zachowana od winy pierworodnej.

${ }_{2}$ T. K e m p i s, O naśladowaniu Chrystusa, (tłum. A. Kamieńska), Warszawa 1981, s. 81.
} 
każdy człowiek ma prawo do dobrego imienia, jednak w relacjach z bliźnimi zdarza się, że ludzie wydają pochopne sądy, kłamią, posługują się obmową czy oszczerstwem, a jednocześnie doświadczają poczucia winy i wstydu. Także człowiek doznający poniżenia odczuwa wstyd.

Problemy związane z przeżywaniem winy i wstydu powinny być rozpatrywane nie tylko z punktu widzenia psychologii czy psychiatrii. Należy podkreślić, że nauczanie moralne Kościoła katolickiego może być zarówno pogłębieniem rozumienia tych zagadnień. Według Katechizmu Kościoła Katolickiego: „Cnoty ludzkie, nabyte przez wychowanie, świadome czyny i wytrwale podejmowane wysiłki, są oczyszczane i podnoszone przez łaskę Bożą"3.

W niniejszym artykule przeprowadzona zostanie analiza lingwistyczna winy i wstydu. Wydaje się, że interesujące będzie wyjaśnienie tych pojęć w świetle polskiej lingwistyki. Język ma złożoną strukturę. Jego podstawową, najmniejszą, względnie samodzielną, znaczącą jednostką, zdolną do pełnienia funkcji syntaktycznych (a zatem i komunikatywnych) jest wyraz (leksem). Może on być analizowany ze względu na różne kryteria, np. ze względu na budowę fonetyczną (akustyczną), formę (orto)graficzną, odmianę fleksyjną, funkcje syntaktyczne. Biorąc pod uwagę cele, które wyznaczyliśmy sobie, wprowadzamy następujące elementy analizy lingwistycznej wyrazów wina i wstyd: pochodzenie (etymologia), znaczenie (semantyka), synonimy i wyrazy bliskoznaczne, antonimy, frazeologizmy, przysłowia i sentencje, derywaty (produktywność słowotwórcza). Należy też dodać, że termin wyraz używamy w dwu znaczeniach: 1) jednostka systemu słownikowego języka (inaczej: leksem), 2) element tekstu.

Analiza lingwistyczna stanowić będzie prolegomena do nauczania Kościoła katolickiego. Uwzględni się perspektywę moralno-biblijną. Wina bowiem i wstyd są najczęściej konsekwencją złego postępowania i grzechu człowieka. W adhortacji apostolskiej Reconciliatio et paenitentia Jan Paweł II przytacza jedną z najbardziej znanych

\footnotetext{
${ }^{3}$ Katechizm Kościoła Katolickiego, nr 1810 (dalej skrót KKK).
} 
przypowieści św. Łukasza o synu marnotrawnym, który po roztrwonieniu majątku ojca wraca do domu głęboko upokorzony i zawstydzony. Uznaje swoją winę wobec ojca, a następnie podejmuje decyzję powrotu i poprawy ${ }^{4}$.

Autorzy będą poszukiwali odpowiedzi na następujące pytania:

Jakie jest pochodzenie i znaczenie terminów: wstyd, wstydliwość, wina, poczucie winy?

Jaka jest specyfika nauczania Kościoła katolickiego odnośnie do winy i wstydu?

Jaka jest ocena moralna wstydu i poczucia winy w świetle nauki Kościoła?

\section{ANALIZA LINGWISTYCZNA WINY}

\section{a. etymologia winy}

Wina, wyraz rodzimy, ogólnosłowiański, por. czes. vina 'przewinienie, przyczyna czego złego', słow. vina 'wina', głuż. i dłuż. wina 'wina' ros. i ukr. winá 'wina, przyczyna', bułg. wina 'przyczyna, przewinienie', scs. vina 'powód, wymówka, wykręt; wina'; kontynuant prsł. *vina $\leftarrow$ *uel-na 'czyn naruszający normy postępowania prawne, obyczajowe, moralne; wykroczenie, występek; błąd, grzech; przyczyna, powód złego; pokrewne z lit. vaina 'błąd, wada', łot. vałna 'przewinienie, błąd', a także łac. vindex 'obrońca, poskromiciel'. Pochodzą od pie. *uei- 'zdążać ku czemuś, ścigać. Pierwotne znaczenie to zapewne 'ściganie (np. przestępcy)' z czego później wykształciło się znaczenie ogólne 'przewinienie's.

${ }^{4}$ Por. Jan Pawe 1 I I, Adhortacja apostolska Reconciliatio et paenitentia, nr 5.

${ }_{5}^{5}$ Por. W. B o r y ś, Stownik etymologiczny języka polskiego, Kraków 2005; K. D ł u g o s z - K u r c z a bowa, Wielki stownik etymologiczno-historyczny języka polskiego, Warszawa 2008. 


\section{b. semantyka}

Wina jest leksemem semantycznie złożonym, który w rozwoju historycznym ulegał istotnym zmianom. Stownik staropolski na podstawie analizy tekstów sprzed XVI w. ustala następujące znaczenie wyrazu wina: 1. 'kara, zwłaszcza pieniężna, może też opłata z racji różnego rodzaju zobowiązań, multa, poena pecuniaria'; 2. 'zarzut, oskarżenie, crimen, accusatio'; 3. 'naruszenie prawa świeckiego, niestosowanie się do nakazów i zakazów religijnych, przestępstwo, grzech, culpa, delictum, crimen'; 4. 'przyczyna, powód, causa'.

W XVI w. dokonuje się radykalna modyfikacja semantyczna. W Stowniku polszczyzny Jana Kochanowskiego ${ }^{7}$ znaczeniem podstawowym analizowanego wyrazu jest 'czyn naruszający normy postępowania, przewinienie, przestępstwo', a w znaczeniu przenośnym 'zarzut, oskarżenie' i dopiero na końcu 'kara'.

W wiekach następnych znaczenie pierwotne podstawowe 'kara pieniężna, grzywna' staje się już tylko znaczeniem historycznym. Zanika też pierwotne znaczenie przenośne 'wada, brak, niedostatek, feler'.

Słowniki 2. połowy XX w. i XXI w. ${ }^{8}$ zasadniczo wydzielają dwa niezależne znaczeniowo, homonimiczne wyrazy: wina I: 'czyn, postępek, zachowanie uznane za wykroczenie, sprzeczne z normami obyczajowymi, moralnymi, z przepisami prawa, przewinienie, grzech,

${ }^{6}$ S. U r b a ń c z y k (red.), Stownik staropolski, t. X, Kraków 1988-1993, (dalej skrót: Słstp).

7 M. K u c ał a (red.), Słownik polszczyzny Jana Kochanowskiego, t. V t-ż, Kraków 2012, (dalej skrót: SPJKoch).

${ }^{8}$ Por. W. D or o s z e w s k i (red.), Słownik języka polskiego, t. IX, T-Wyf, Warszawa 1967 (dalej skrót: DorSJP); M. S z y m c z a k (red.), Słownik języka polskiego, t. III, R-Ż, Warszawa 1981 (dalej skrót: SzymSJP); B. D u n a j a (red.),Słownik współczesnego języka polskiego, Warszawa 1996 (dalej skrót: SWJP); M. B a ń k a (red.), Inny słownik języka polskiego, t. II, P-Ż, Warszawa 2000 (dalej skrót: ISJP); $\mathrm{S}$. D u b i s z (red.), Uniwersalny słownik języka polskiego, t. V, W-Ż, Warszawa 2003 (dalej skrót: USJP); H. Z g ó 1 k o w a (red.), Praktyczny słownik współczesnej polszczyzny, t. 45 (wańczas-wniknięcie), Poznań 2004 (skrót PSWP). 
występek', np. Kara za winy. Przyznać się do winy. Przedstawić dowody winy. wina II: 1. 'odpowiedzialność za czyn będący wykroczeniem, naruszający normy prawne', np. Ponosić winę za coś. Obarczać kogoś wina; 2. 'bycie sprawca czegoś złego, niepożądanego; także to, co przynosi złe skutki, co jest przyczyną czegoś złego, np. To nie jest jej wina. Czy to moja wina, że on zachorowat ?9

$\mathrm{W}$ rozwoju semantycznym leksemu wina w polszczyźnie dostrzegamy ewolucję znaczeniową od konkretu do abstraktu: 'kara pieniężna, grzywna' $\rightarrow$ 'czyn naruszający normy postępowania, przestępstwo' $\rightarrow$ 'zarzut, oskarżenie' $\rightarrow$ 'odpowiedzialność za czyn będący wykroczeniem’ $\rightarrow$ 'przyczyna czegoś złego'.

Wina funkcjonuje jako wyraz polszczyzny ogólnej oraz jako termin, głównie z dziedziny etyki i z dziedziny prawa. Znaczenie wskazuje i precyzuje kontekst.

\section{c. synonimy i wyrazy bliskoznaczne}

Prezentowany tu słowniczek synonimów i wyrazów bliskoznacznych leksemu wina został opracowany na podstawie dawnych i współczesnych słowników polszczyzny ogólnej oraz słowników specjalistycznych ${ }^{10}$. Nie zawiera dokumentacji tekstowej ani użyć kontekstowych, ponieważ taki materiał nadmiernie powiększyłby objętość artykułu. A celem tego rozdziału jest jedynie pokazanie, jak bardzo jest szeroki zakres znaczeniowy omawianego leksemu, skoro ma tak bardzo bogatą (ilościowo i jakościowo) synonimię.

Synonimy i wyrazy bliskoznaczne w układzie alfabetycznym: błąd, bezprawie, bestialstwo, barbarzyństwo, barbaria, bezsenna noc, fałszywy krok, faul, grzech (młodości), grzeszki, grzeszność, gafa, kara, karygodność, naruszenie prawa, nieczyste sumienie,

9 Podaję za: Słownik współczesnego języka polskiego, dz. cyt.

${ }^{10}$ R. Z a w i l i ń s k i, Dobór wyrazów. Słownik wyrazów bliskoznacznych i jednoznacznych, Kraków 1926; S. S k o r u p k a, Słownik wyrazów bliskoznacznych, Warszawa 1971; A. D ą b r ó w k a, E. G e 11 e r, R. Tu r c z y n, Słownik synonimów, Warszawa 1993; A. D ą b r ó w k a, E. G e 11 e r, Słownik antonimów, Warszawa 1995. 
niedopatrzenie, niegodziwość, nieposłuszeństwo, nieprawość, nieuczciwość, obraza (majestatu), odpowiedzialność, okrucieństwo, opuszczenie, oszustwo, poczucie winy, potępienie, przekroczenie prawa, przemycanie, przeoczenie, przestępstwo, przewina, przewinienie, sprawka, sprawki, uchybienie, usterka, współodpowiedzialność, współwina, wybieg, wykroczenie, wyrzuty sumienia, występek, występki, zaniedbanie, zbrodnia, zdrada, złamanie słowa, złe sumienie, zobowiązanie.

Przedstawione synonimy i bliskoznaczniki ukazują całą gamę odcieni znaczeniowych, stylistycznych i chronologicznych leksemu wina.

\section{d. antonimy}

Najogólniej definiując, stwierdzamy, że antonimy to wyrazy o przeciwstawnych znaczeniach. W językoznawstwie współczesnym w obrębie tak ogólnikowo zdefiniowanej kategorii wyróżnia się antonimy właściwe oraz wyrazy o znaczeniach komplementarnych i konwersje ${ }^{11}$. Stwierdzamy również, że w odniesieniu do winy mamy do czynienia przede wszystkim z antonimami o charakterze konwersji.

Leksem wina jest wieloznaczny i w ciągu rozwoju historycznego podlegał różnym modyfikacjom semantycznym, różne też były użycia kontekstowe tego wyrazu - dlatego też każda para antonimiczna wymagałaby szczegółowej analizy. Tu zatem odwołamy się tylko do materiałów leksykograficznych ${ }^{12}$, zaznaczając jedynie, że te materiały wskazują przede wszystkim na moralny aspekt winy. Oto wykaz wyekscerpowanych par antonimicznych:

${ }^{11}$ S. U r b a ń c z y k (red.), Encyklopedia wiedzy o języku polskim, Wrocław-Warszawa-Kraków-Gdańsk 1978, informuje, że antonimy właściwe podlegają stopniowaniu, np. wysoki - niski, wyższy - niższy; natomiast dla wyrażeń o znaczeniach komplementarnych jest charakterystyczne, że zaprzeczenie jednego powoduje stwierdzenie drugiego, np. nie jest żonaty = jest kawalerem. Przykładem konwersji

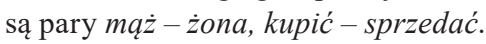

${ }_{12}$ A. D ą b r ó w k a, E. Geller, Słownik antonimów, dz. cyt. 
Wina - niewinność, brak winy, fair play, zgodność z zasadami, zachowanie zasad, przestrzeganie prawa, nieskazitelność; - uczciwość, czystość, alibi, czyste sumienie, spokojny sen, sen sprawiedliwego, rozgrzeszenie, odpuszczenie grzechów. Niektóre pary antonimiczne z członem wina mogą zaskakiwać, ale jednocześnie zmuszają do refleksji nad bogactwem niekiedy ukrytych odcieni znaczeniowych opisywanego leksemu.

\section{e. frazeologizmy}

Wina występuje w ustabilizowanych połączeniach wyrazowych, które mają strukturę wyrażeń, zwrotów, niekiedy fraz. Pod względem znaczeniowym odnoszą się do sfery obyczajowej, moralnej i prawnej. Zwraca uwagę duża liczba frazeologizmów (choć nie są to wszystkie struktury zarejestrowane w słownikach i innych materiałach źródłowych, lecz tylko te, o największej frekwencji występowania).

Wyrażenia: bita wina 'kara pieniężna za pobicie' (Słstp, L); ciężka wina (KKK 2354), np. Pornografia jest ciężką winą; kara za winy (SWJP); miłosna wina 'kara zależna od łaski karzącego' (Słstp); pierworodna wina (KKK 390; 966) 'grzech pierworodny'; wina dworna 'wina (grzywna, kara) należna dworowi' (SW); wina główna 'kara śmierci' (Słstp); wina komu 'wada' (L, SW); wina nieumyślna 'wina polegająca na zlekceważeniu możliwych skutków swojego postępowania lub na nieprzewidzeniu ich, choć można je było przewidzieć' (USJP, PSJP); wina panieńska 'utrata panieństwa' (SPJKoch); wina ranna 'odszkodowanie za poniesione rany' (Słstp); wina złodziejska 'oskarżenie o kradzież (Słstp); wina umyślna 'wina polegająca na zamiarze popełnienia czynu przestępczego lub godzeniu się na możliwe skutki swojego działania (USJP, PSJP).

Zwroty i frazy: brać winę na siebie (SzymSJP, Słfraz ${ }^{13}$, USJP, PSJP); brać winę z kogo 'skazać kogo na karę pieniężną (L, SW); cierpieć za (nie) popetnione winy (PSJP); dać, dawać wine 'oskarżać o co'

${ }_{13}$ S. S k o r u p k a, Stownik frazeologiczny języka polskiego, t. II, Warszawa 1967 (dalej skrót: Słfraz). 
(Słstp, L); darować komu wine, winy (SWJP) \|darować, przebaczyć komuś wine (SzymSJP, USJP, PSJP); dowieść komu winy (SzymSJP, USJP, PSJP); moja to będzie wina 'biorę to na siebie' (L, SW); (nie) poczuwać się do winy (SW, SzymSJP, USJP); obarczyć kogoś wina (Słfraz, SWJP, USJP); odkupić winy (Słfraz, SWJP); odpokutować, odpuścić winę (Słfraz, PSJP); odkupić winę (Słfraz); orzec o czyjejś winie (PSJP); poczuwać się do winy (Słfraz); pokutować za czyje winy (SW, Słfraz); ponieść winę za czyjeś krzywdy, za spowodowanie wypadku (USJP); ponosić winę za coś (Słfraz, SWJP); popaść w winę 'popełnić przestępstwo' (DorSJP daw.); przyznać się do winy (SW, USJP); rozgrzeszyć, oczyścić kogoś z winy (PSJP); udowodnić komuś wine (Słfraz, PSJP); wierzyć w czyjąś wine (Słfraz, PSJP); wina ciąży na kimś (SzymSJP, Słfraz, USJP, PSJP); wina leży (jest) po czyjejś stronie (Słfraz, USJP, PSJP); wina nie była ze mnie 'to nie ja byłam przyczyną' (L); winę odłożyć 'zapłacić grzywnę' (L); winę włożyć na ziemię 'nałożyć karę na kraj' (SW); wina spada na kogo 'ktoś staje się moralnie odpowiedzialny za co' (DorSJP, PSJP); wyrzucać, zarzucać komuś wine (PSJP); wyznać swoją winę (SzymSJP, USJP); wziać, przyjąć na siebie (całą winę) 'obciążyć siebie odpowiedzialnością za co’ (DorSJP); zaprzeć się winy (PSJP); zepchnacć, złożyć, zwalić (składać) winę na kogo 'obciążyć kogo odpowiedzialnością za wykroczenie popełnione przez samego siebie' (SW, DorSJP, USJP); zmazać, zmyć, zrzucić z siebie wine (Słfraz, SzymSJP, PSJP, USJP); znaleźć do kogo wine 'mieć powód do kary' (SW); zrzucić z siebie wine 'usprawiedliwić samego siebie' (WSFPWN ${ }^{14}$, USJP, Słfraz); zrzucać cała winę na kogoś (SWJP); złożyć, zrzucić, zwalić winę na kogoś (SzymSJP, USJP, PSJP).

\section{f. przysłowia i sentencje}

Zwykło się mawiać, że przysłowia są mądrością narodu czy nawet narodów. Te przysłowia i sentencje, które funkcjonują w polszczyźnie

${ }_{14}$ A. Kło s iń s k a, E. S o b o 1, A. S t a n k i ew i c z (oprac.), Wielki słownik frazeologiczny PWN z przystowiami, Warszawa 2005 (skrót: WSFPWN). 
od wieków, zapewne odzwierciedlają i zarazem kształtują nasz kodeks etyczny. Poniżej podajemy najlepiej udokumentowane leksykograficznie $^{15}$ przysłowia w układzie alfabetycznym.

Dwakroć grzeszy, ktokolwiek winy się nie wstydzi 'winę pogłębi brak żalu, skruchy' (L, PSJP); Gniew i winę odpuścić nieprzyjacielom (L); Kto się do winy sam przyznaje, ten niewinny zostaje 'zrozumienie własnych błędów i przyznanie się do nich może pomóc w odzyskaniu ludzkiego zaufania' (PSJP); Lepiej winę darować, niżli się prawować 'należy wybaczać innym' (PSJP); Łacno wilk znajdzie do barana winę (L); Małe winy gryziemy, wielkie całkiem połykamy 'czasem łatwiej wybaczyć wielkie przewinienie niż nieznaczne' (PSJP); Nie masz winy bez przyczyny 'każdy zły czyn ma swoją przyczynę' (PSJP); Nie ma zbrodniarza bez winy, nie ma śmierci bez przyczyny 'wszystko ma swoją przyczynę' (PSJP); Nie ma winy bez kary 'każdy zły czyn musi mieć swoje konsekwencje' (PSJP); Nikt nie jest bez winy 'każdy ma coś na sumieniu' (PSJP); Nie szukaj winy u innych (SzymSJP); Pierwsza wina darowana, druga wymawiana, trzecia obijana 'nie można darować win bez końca (PSJP); Pót winy się daruje, kto sam się przyznaje "przyznanie się do winy w znacznym stopniu łagodzi karę' (PSJP); Prawa są równe jako pajęczyna, wróbl się przebije, a na muszkę wina (J. Kochanowski); Próżno ten drugiego karze, kogo takaż wina maże 'nie można karać kogoś za występki, których sami się dopuszczamy' (SW, PSJP); Przed przekonaniem o wine, wskazywać kary nie przystoi 'przed poznaniem sprawy nie należy ferować wyroku (L); Przyznaje się do winy, kto od sądu stroni 'unikanie rozstrzygnięcia sprawy świadczy o winie' (PSJP); Sobie wybaczamy wine, cudzym kwaśna stroimy minę 'łatwiej wybaczamy sobie niż innym' (PSJP); Tam zaraz przypisuja wine, gdzie nie towarzyszyło szczęście (L); Wina leży po środku 'obie strony sporu, konfliktu itp., częściowo mają rację, są częściowo winne’ (WSF PWN);

15 Materiał pochodzi z następujących słowników: Słstp., SPJKoch, L, SWil, SW, SzymSJP, DorSJP, PSWP, SWJP, ISJP, USJP, SSłfrazjp., SłfrazWP, WSfrazJP, WSFrazPWN. 
Winę czlowiek sam sobie wyrzuca (SWil); Za grzechem idzie wina albo zmaza na duszy 'grzech pozostawia trwałe ślady' (L, SWil).

\section{g. derywaty}

Analiza lingwistyczna jakiegoś wyrazu powinna doprowadzić do określenia miejsca tego leksemu w systemie językowym. Sądzę, że to miejsce determinuje wiele czynników. Najważniejsze z nich zostały już tu omówione: pochodzenie (etymologia), znaczenie - ewolucja i relacja z innymi leksemami oparta na zasadzie synonimii i antonimii, a także ustabilizowane połączenia wyrazowe (frazeologia, przysłowia, sentencje). O miejscu wyrazu w systemie decyduje jeszcze jeden ważny element - czynnik morfologiczny. Należy stwierdzić, że wina jest bardzo produktywną bazą derywacyjną. Oto przegląd formacji pochodnych ${ }^{16}$.

Rzeczownik wina tworzył dość rozbudowaną rodzinę wyrazową, która obejmowała formacje czasownikowe, rzeczownikowe i przymiotnikowe.

Formacje czasownikowe: winić (XV w.) 'przypisywać komu winę, uważać za winnego; oskarżać, np. przysł. „Jeśliś sam nie bez winy, nie wiń drugiego”; „Sumienie mię w niczym nie wini, bo idę prawdy drogami” (F. Karpiński, SJP); „Winisz mnie? jaki dowód mojej masz niewiary?" (F. Zabłocki, SJP). Por. też czasowniki prefiksalne: dowinić (XVI w.) 'popełnić winę', fraz. dowinić się czego 'dopuścić się jakiej winy, zbroić co', np. „Kalimach radził Olbrachtowi, aby nie odpuszczał żadnemu szlachcicowi, gdy się który czego dowini" (M. Bielski, L); obwinić, obwiniać (XVI w.) 'oskarżać, obciążać winą', np. „Obwiniam kogo o co” (K); „Dwoma grzechami Dawid król był obwiniony” (I.M. Kuligowski, L); „Trzeba wiedzieć, kto ma być powodem, aktorem, a kto obwiniony" (B. Groicki, L); „Nie chcę jej obwiniać przed tobą, ale przez całe życie swe

16 Pozdaję za: K. D 1 u g o s z - K u r c z a bo w a, Wielki stownik etymologiczno-historyczny..., dz. cyt. 
nigdy taktu i rozsądku w postępowaniu nie okazała" (J.I. Kraszewski, SJP); także rzeczowniki odczasownikowe: obwiniacz, obwiniciel (L) 'oskarżyciel', np. „Gdzież są oni obwiniacze twoi? nikt cię nie osądził?” (J. Seklucjan, L) oraz obwinicielka - forma żeńska; owiniać (L) 'obwiniać'; przewinić, przewiniać (się) 'popełnić przestępstwo, dopuścić się wykroczenia', przysł. Kto przewinił, niech płaci $(\mathrm{K})$, Jakie przewinienie, takie dość czynienie $(\mathrm{K})$; fraz. przewinić komu 'występować przeciw komuś', np. „Czymem ci przewinił, w czymem krzyw tobie, żeś tak nieludzka ku mej osobie?” (Zabawy Przyjemne i Pożyteczne, L); „Cóż nieszczęsna Elwira mogła ci przewinić, żeś ją starał się gwałtem występną uczynić” (A. Fredro, SJP); „Nikt nie ucieka, jedno przewiniony pospolicie" (Grzegorz z Żarnowca, L), a stąd: przewinienie 'postępek uznany za przestępstwo', np. „Łoił batem za przewinienie aże skóra trzeszczała" (S. Żeromski, SJP); przewina 'przewinienie', por. „Jeśli wy będziecie odpuszczać ludziom grzechy albo przewiny ich, odpuści i wam pan występki wasze" (Leopolita, L), „Wymiar kary powinien być w jakiejś proporcji do przewiny" (M. Ossowska, SJP); fraz. odszczekiwać przewine 'publicznie przyznać się do winy, odwołując oszczerstwo (pierwotnie niekiedy pod stołem i na czworakach)', np. ,Jeszcze czulszym okazywał się statut małopolski za obrazę honoru. Oszczerca niewiasty odszczekiwał przewinę" (K. Szajnocha, SJP), a także przewiniciel (XIX w.) 'ten, kto popełnił przewinę', np. ,Jako przewiniciel godny jego (Boga) grzmota, ja sam przeciwko prawu świętemu żywota stanę zawinicielem" (J. Słowacki, SJP); uwinić (XVI w.) 'za winnego uznać; oskarżyć, np. „Nie masz tak złej rzeczy, w którejby złoto w dobrą nie obróciło, a nie masz też tak dobrej, którejby w złą obrócić nie mogło; snadnie może uwinić sprawiedliwego, a wyzwolić niesprawiedliwego" (M. Rej, L); wywinić, wywiniać (L) ' $\mathrm{z}$ winy uwolnić, uniewinnić, np. „Tacyt sam chrześcijan z podpału Rzymu wywinia” (A. Naruszewicz, L); wywiniony 'uniewinniony'; zawinić, zawiniać (L) 1) 'winnym się stać; popełnić przewinienie', np. „Libonius, iż był wielce zawinił cesarzowi, gdy mu dwie armacie poraził, dlatego przed gniewem jego dalej uchodzić musiał” (M. Stryjkowski, L); „Zawinienie, wina, której się kto dopuścił” (L); „Dawno przebaczyłam mu 
wszystko, co tylko względem mnie zawinił" (E. Orzeszkowa, SJP); 2) 'zostać komu winnym, dłużnym', np. „Chłopcu powiedział, że mu Żydzi w miasteczku za garnki zawinili i kazali po jarmarku przyjść po pieniądze" (J.I. Kraszewski, SJP); zawiniony 'popełniony przez kogoś, jako czyn obarczający sprawcę winą' oraz niezawiniony, $\mathrm{np}$. (nie)zawinione przez sprawce przestępstwo i pochodny rzeczownik zawiniciel (SJP) 'ten, kto zawinił', np. „Sam przeciwko prawu świętemu żywota stanę zawinicielem" (J. Słowacki, SJP); zwinić (XVI w.) ‘oskarżyć, uznać za winnego', np. „Jeśliby cię mógł zwinić, albo urzędowi oddać, już tam miłosierdzia nie znajdziesz" (M. Rej, L); „Krystus winy, któremi my zwinieni jesteśmy, na się przyjął” (P. Gilowski, L); ,Jeden pochwali wyroki, drugi zwini, W słuszności ocznej są niezgodne duchy" (Zabawy Przyjemne i Pożyteczne, L) winować (XVI w.) 'za winnego uznawać, oskarżać', np. „Ponieważ karanie tylko na ciele bywa, a szaleni na ciele nic nie cierpią, przeto nie karani, ale tylko winowani bywają” (P. Szczerbic, L); „Któż jest na świecie, aby się winował, każdy niewinnym zda się człowiek sobie" (J.S. Jabłonowski, L); „Wy pana Kmicica nie winujcie, bo choćby co i przeciw stateczności uczynił, to młody jest, a oni go kuszą, oni podmawiają, oni zachęcają do rozpusty" (H. Sienkiewicz, SJP) [oraz wyrazy pochodne od tego czasownika: winowat $\mathrm{i}$ w formie odmiany złożonej winowaty (XVI w.) 'winę mający', por. np. „Winowat, winowaty, co przewinił w czym” (I. Włodek, L); „Nie płaci bogaty, płaci winowaty” (A. Rysiński, L); „O długi i o inne krzywdy z tymi winowatymi wieśniakami u panów ich sprawiedliwości dochodzić trzeba” (Statuty litewskie, L); „Odpuść winy, serca nasze niech do odpuszczenia zawsze skłonne będą winowatym" (Kancyonał gdański, L); por. wyrazy pochodne: winowatość (L) 'podleganie winie' oraz nazwy osobowe: winowaciec (XV w.), winowajca ( $\leftarrow$ winowaćca) 1) 'ten, który przewinił', np. „Musi niewinny przegrać przed sądem winowajcy” (Monitor, L); „Kto bowiem ubił zwierza, był pociągany do sądu jako winowajca” (J.W. Bandtkie Stężyński, SJP); 2) 'dłużnik', np. „Winowajcy za umowę słuszną, winę albo dług powinni płacié” (P. Gilowski, L); ,ten, który pieniędzy pożyczył, pozwał o to swego winowajcę" (J. Herburt, L); oraz nazwy żeńskie: winowajczyni (L), 
np. „Byłby się zawahał winowajczynię rękami własnymi na gorejący zanieść stos i w płomień rzucić" (T.T. Jeż, SJP), winowajczyna (L), np. „Będąc winowajczyną, nie wartam go zgoła” (J. Przybylski, L).

Formacje przymiotnikowe: winien i w odmianie złożonej winny (XIV w.) 1) 'który zawinił, na którym ciąży wina', np.: „Kto się chce prawa nie bać, nie bądź winien" (M. Rej, L);, Prawa się winny boi, nieszczęścia niewinny” (J.E. Minasowicz, L); „Dla jednego winnego niewinnym źle się dziać nie ma" (P. Skarga, L); 2) 'zobowiązany do czego', np. „Biskup rzymski winien się starać, aby wszędzie ewangelia opowiadaną była” (J. Boter, L); „Winien czcić męstwo ten, co zwycięża” (L); 3) 'stosowny, należny, słuszny', np. „Pozostaję z winnym szacunkiem” (SW); „Odebrał winną zapłatę” (SW); 4) 'dłużny, mający obowiązek zwrócenia', np. „Dusił go, mówiąc: oddaj, coś winien” (J. Wujek, SW); „Był winien pewną sumę pieniędzy” (J. Kochanowski, SW); fraz. przen. Bogu ducha winien 'zupełnie niewinny'; winnym być komu za co 'zawdzięczać mu co', np. „Wszystkość winien twym przodkom, będąc nikczemnikiem: potomni nic nie będą winni ci pewnikiem” (J.E. Minasowicz, L); „Winienem wszystko tobie, wielebny ojcze, bo bez twojej łaski mój brzuch był czczy, a głowa próżna" (H. Rzewuski, SW) [por. pochodne: niewinny (XVI w.) w użyciu rzeczownikowym, np. „Niewinnemu przy winnym się dostanie” (K); „Lepiej winnemu przepuścić, niż niewinnego karać” (K); oraz rzeczownik niewinność (XVI w.), np. „Za kim niewinność chodzi, jak we stu koni jeździ” (A. Fredro, L); „Chciał pan sądownie a jawnie w niewinności swej być skarany, abyśmy my winnościom naszym odpuszczenie mieli" (Grzegorz z Żarnowca, L); i pochodne czasowniki odprzymiotnikowe uniewinnić, uniewinniać (L) 'uznać za niewinnego', np. „Uniewinnić kogo przed sądem” (SW); tu można także zaliczyć bezwinny (XVI w.) 'niewinny, od winy wolny', por. np. „Każdy siebie bezwinnie osądził” (D. Pilchowski, L); „Bezwinnie cierpiący ma tę pociechę, że go Bóg kocha” (K. Balsam, L); „Kniaź wiele szkód poddanym bezwinnie uczynił" (M. Stryjkowski)'] tzn. 'na które nie zasłużyli' (L) i pochodne: bezwinność (L) 'niewinność']. Od wyrażenia przyimkowego po winie pochodzi powinien, powinna, 
powinno - przymiotnik w odmianie prostej, używany w funkcji orzecznika powinien jest 'ma obowiązek pewny', wtórnie z cząsteczkami osobowymi: powinieniem, powinieneś (...) powinnam, powinnaś (...) oraz w odmianie złożonej, zaimkowej: powinny, powinna, powinno 1) 'obowiązany, należny', por. np. „Być powinnym, albo być obowiązanym, są to słowa jednegoż znaczenia” (Monitor, L); Żaden nie powinien być bogatym, jeno cnotliwym” (A. Rysiński, L); „My na większe wyższych cnot i gorętsze naśladowanie powinni jesteśmy" (P. Skarga, L); „Jakimże sposobem za tyle łask i dobrodziejstw moje powinne dziękczynienie wyrażę" (J. Lelewel, SJP); 2) 'krewny, powinowaty', np. „Czechowie, Polaków powinni” (M. Kromer, L); „Jakub mniejszy, brat powinny Pana Jezusa" (P. Skarga, L); Jesteśmy sobie krwią powinni, nie godzi się nam w niezgodzie żyć" (P. Skarga), tj. 'krewni' - „Krwią do siebie należący” (L); „Prawo nie pozwala, żeby powinny powinnego sądził" (H. Rzewuski, SJP). Formacje pochodne: powinność (XV w.) 1) 'obowiązek, posługa powinna', np. „Powinność każdego pana w powszechnych klęskach ratować poddanych” (Teatr, L); „Chłopstwo było obowiązane do pewnych powinności (...) Te zaś powinności (...) były, tak płata pieniężna, jako posługa dworowi, w robociźnie na gruncie pańskim" (A. Naruszewicz, SJP); 2) 'obowiązek, konieczność natury moralnej', np. „Dążyli do zrzucenia z siebie wszelkich powinności obywatelskich” (T. Parnicki, SJP); „Umiejętne władanie ojczystym językiem jest powinnością każdego poczciwego, oświeconego człowieka" (A. Groza, SJP); 3) 'powinność, powinowactwo', np. „Na powinowactwo w małżeństwach uczynione są prawa, aby żaden nie śmiał praw przestępować, tak w krewności, to jest z linii ojcowskiej, jako też z powinności po żonach i mężach" (P. Skarga, L); powinowaty (XVI w.) 1) 'spowinowacony; mający z kim powinowactwo', np. w użyciu rzeczownikowym: „Powinowaci, affines, są krewni męża z jednej, a żony z drugiej strony" (T. Ostrowski, L); „Mąż jest powinowatym siostry żony, ale małżonkowie dwóch sióstr nie są ze sobą spowinowaceni w rozumieniu Dekretu" (F. Zoll, SJP); 2) 'zobowiązany, zobligowany' daw., np. „Jeszcze $\mathrm{z}$ dzieciństwa twego zawżdyś jest powinowat posłuszeństwo Bogu, a zawżdyś jest powinowat chodzić wedle woli świętej jego" (M. Rej, 
L); „U nas dziś wdzięczności powinowatej nie znajdzie” (B. Herbest, L) oraz powinowactwo (XVI w.) 1) 'powinność, obowiązek', np. „Urzędnicy niech urzędy według powinowactwa wypleniają” (J. Herburt, L); „Która sługa dwiema panom służyć chce, nigdy taki jednemu wiernie a wedle powinowactwa swego zachować się nie może” (M. Rej, L); 2) 'krewność' daw., np. „Prawo krewności abo powinowactwa” (Prawo chetmińskie, SW); „W jakim stopniu jednego z małżonków pokrewieństwo zachodzi, w tymże stopniu drugiego powinowactwo" (T. Ostrowski, L); 3) zb. 'powinowaci, rodzina', np. „Wszystkie powinowactwo po nim w żałobie” (T); 4) chem. „Powinowactwo chemiczne, siła utajona w ciałach, za której pomocą przyciągają się wzajem lub zbliżyć się do siebie usiłują" (J.K. Mieroszewski, L); powinowatość (XVI w.) 1) 'powinowactwo', np. „Powinowatość po ojcu” (T); 2) 'powinność', np. „W Panu Bogu a w tej egzekucji nadzieja jest, co się pokaże z powinowatości królewskiej” (S. Orzechowski, SW); powinowacić, spowinowacić (L) 'powinowatym uczynić' oraz powinowacić się 'stawać się powinowatym', np. „Przystojną zazdrością był wzruszon, zapatrując się na sławę tego, z którym go przypadek urodzenia powinowacił” (I. Krasicki, SJP).

\section{ANALIZA LINGWISTYCZNA WSTYDU}

\section{a. etymologia wstydu}

Wstyd to wyraz rodzimy, ogólnosłowiański (por. czes. stud 'wstyd, wstydliwość', stydký 'haniebny, ohydny', styděti se 'wstydzić się', ros. styd, ukr. styd, bułg. stid, sch. stîd); przy czym słow. formy $\mathrm{z}$ rdzenną samogłoską $y \| i$ kontynuują prsł. rdzeń *stydz oraz pie. $s t \bar{u}$-, natomiast wyrazy z rdzenną samogłoską $u$ kontynuują prsł. *studb oraz pie. *stou-. Pokrewne rdzenie występują m.in. w lit. stúgti 'sterczeć, wystawać' oraz grec. stygéo 'boję się, 'nienawidzę'. $\mathrm{Z}$ prsł. rdzeniami *stud-, *styd- było związane zn. 'zimna, chłodu'; przetrwało ono m.in. w pol. czasownikach studzić 'chłodzić, ziębić', por. też prefiksalne ostudzić, przestudzić, wystudzić 'uczynić chłodniejszym, oraz stpol. stydnąć (por. przen. „Miłość ziębnie, stydnie 
nabożeństwo", J. Wujek, SW), nowsze stygnąć i paralelnie ostygnąć, przestygnąć, wystygnąc 'zimniejszym się stać' oraz w rzeczownikach ostuda (L) 'ostudzenie, zaziębienie, por. „Duszność, kaszle, ostuda, ziębiączki jesienne" (XVIII w., L); studnica (L) 'krynica, zdrój, źródło'; studnia (L) 'otwór w ziemi lub skale z odpowiednim urządzeniem, umożliwiającym wydobywanie wody'; studzienina (SWil) 'galaretka mięsna, czyli zimne nóżki'. Oprócz tego zn. z zakresu doznań fizycznych 'chłód, ziębnięcie' ustabilizowało się drugie zn. dotyczące sfery psychicznej, moralnej; zapewne według schematu 'zimno, chłód' $\rightarrow$ 'nieprzyjemne doznania fizyczne' $\rightarrow$ 'przykre odczucia psychiczne' $\rightarrow$ 'wstyd'. Mechanizm wykorzystywania nazw o zn. fizycznym, konkretnym do określania doznań psychicznych jest częsty, por. np. mierzić 'mrozić' $\rightarrow$ 'obrzydzać'; puszyć się 'stawać się pustym, nadymać się' $\rightarrow$ 'stawać się zarozumiałym'; przerazić 'przebić razem, zadać cios' $\rightarrow$ 'przestraszyć' 17 .

\section{b. semantyka}

Wyraz wstyd występuje w polszczyźnie od najdawniejszych czasów w kilku odcieniach znaczeniowych: 1) „wstydliwość, skłonność przyrodzona do wstydania się, sromięźliwość uczciwa" (K) oraz związane z tym 'przykre, upokarzające uczucie spowodowane świadomością niewłaściwego postępowania; konfuzja', np. „Wstyd nic innego nie jest, jeno, jak stoikowie wykładają, bojaźń złej sławy" (XVI w., L), „Dla wstydu, radbym się pod ziemią widział” (K), „I wstydu i dobrej sławy zapomniała” (J. Kochanowski, SW); 2) 'niewinność, skromność, cnota', np. ,Jak to w tych czasach rychło panienki wstyd tracą” (XVIII w., L); 3) 'to, co wstyd czyni; wstydliwe części ciała', np. „Miejsce wstydu zakryć” (XVI w., L).

Zakres znaczeniowy wyrazu wstyd w początkach polszczyzny jest więc szeroki: obejmuje zarówno sens abstrakcyjny 'wstydliwość, jak i treści znaczeniowe bardziej konkretne: 1) subiektywne: 'wstydzenie

${ }_{17}$ Opracowano na podstawie: K. D $\nmid$ u g o s z - K u r c z a bowa, Wielki słownik etymologiczny..., dz. cyt. 
się, zawstydzenie' oraz 2) obiektywne: a) 'to, co wstyd czyni, złe uczynki' i b) 'członki wstydliwe'.

W rozwoju historycznym polszczyzny te znaczenia wzajemnie się przenikają. Świadczy o tym m.in. definicja wyrazu zamieszczona w Słowniku polszczyzny Jana Kochanowskiego ${ }^{18}$ : 'zasady moralne, uczucia, hamulce powstrzymujące człowieka od złych, nieakceptowanych zachowań, rumieńce, obawa przed zrobieniem czegoś, co może zostać wyśmiane, skrytykowane, przykre uczucie spowodowane własnym lub cudzym zachowaniem, które się okazało złe, głupie, niestosowne, rozczarowanie z powodu wyboru niewłaściwej drogi, podjęcia złej decyzji, zdania sobie sprawy, że to było błędne, naiwne, hańba, potępienie'.

W dobie nowopolskiej nadal funkcjonują znaczenia wstydu: 'wstydliwość', czyli 'uczucie wstrzymujące od złych postępków, od ich widoku, przez bojaźń niesławy, hańby', a które „w ogólności znamionuje się rumieńcem nagłym na twarzy” (SWil); "wstydzenie się', czyli 'przykre uczucie w człowieku, gdy zły jego postępek stanie się wiadomy ludziom i ci mu to wyrzucają, albo też gdy sam poczuje się do winy lub do słabości, niższości' (SWil). Stopniowo wychodzą z użycia znaczenia 'niewinność, dziewictwo, cnota' oraz 'członki wstydliwe, narządy płciowe'. Uzyskują one status archaizmów semantycznych. Natomiast nowym zjawiskiem jest powiązanie znaczenia $\mathrm{z}$ określoną konstrukcją syntaktyczną: wstyd + bezokolicznik, np. wstyd mówić, wstyd stuchać, wstyd pomyśleć 'odczuwam wstyd, jestem zawstydzony w związku z tym, co mówię // mówisz, słyszę // słyszysz, pomyślę // pomyślisz...', a zatem: 'nie należy tego mówić, słuchać, pomyśleć'.

W najnowszych opracowaniach (B. Dunaj, H. Zgółkowa) te różne, odrębne znaczenia jednego wyrazu stały się podstawą do wydzielania dwóch jednobrzmiących wyrazów, czyli homonimów: wstyd I 'nieprzyjemne, upokarzające uczucie wywołane świadomością własnych lub cudzych braków, błędów, złych, niewłaściwych postępków, połączone z lękiem przed opinią innych, np. Przyniósł wstyd rodzinie,

18 Stownik polszczyzny Jana Kochanowskiego..., dz. cyt. 
oraz wstyd II a) 'wstydzić się; czuć się zakłopotanym; odczuwać dyskomfort psychiczny w związku z niewłaściwym zachowaniem; np. byto jej wstyd, za to, co zrobiła; b) 'należy się wstydzić, należy czuć się zakłopotanym’, np. wstyd obmawiać ludzi.

\section{c. synonimy i wyrazy bliskoznaczne ${ }^{19}$}

Wstyd-zakłopotanie, zmieszanie, zawstydzenie, zawstydzenie się, skrępowanie, skonfundowanie, zażenowanie, żenada; upokorzenie, pośmiewisko, konfuzja, zakłopotanie; pąs, rumieńce; hańba, potępienie, ujma, niesława, kompromitacja, infamia, zakłopotanie, nieśmiałość, onieśmielenie, skromność, cnota; wstydliwość (przyrodzona); niewinność, dziewictwo, panieństwo, prawictwo, wianek; członki wstydliwe, części płciowe; srom, sromota, sromotna rzecz, sromotny uczynek, sromiężliwość; sromanie się; zmieszanie. Wielość i różnorodność synonimiki wyrazu wstyd wynika z jego wieloznaczności.

\section{d. antonimy $^{20}$}

Wstyd - cześć, hołd, uznanie; sława, chwała, śmiałość, pewność siebie; duma; bezwstyd, nieskromność, nieczystość, plugawość, bezwstydność, cudzołóstwo, nierząd, prostytucja; chełpliwość, nadętość, napuszoność, pretensjonalność, krygowanie się, afektacja, emfaza; tupet, brak wstydu, napraszanie się, wpraszanie się, nachalność, namolność, narzucanie się, dokuczliwość.

19 Opracowano na podstawie: A. D ą b r ó w k a, E. G e 11 e r, Słownik antonimów..., dz. cyt., oraz SPJKoch, L, SW, SWil, DorSJP, PSWP, USJP; A. D ą b r ó w k a, E. G e 11 e r, R. Turczyn, Stownik synonimów, dz. cyt.

${ }^{20}$ Opracowane na podstawie: A. D ą b rów k a, E. G e 11 e r, Słownik antonimów..., dz. cyt., oraz PSWP, ISJP. 


\section{e. frazeologizmy}

Wstyd tworzy liczne i trwałe związki frazeologiczne zarówno o strukturze wyrażeń, jak i zwrotów i fraz.

Wyrażenia: że aż wstyd; aż wstyd; co za wstyd; jaki wstyd; to wstyd - 'wykrzyknienie, stwierdzenie wyrażające potępienie czyjegoś postępowania, czyichś słów'; dziewiczy wstyd; fatszywy wstyd; gtęboki wstyd; gryzacy wstyd; hańba i wstyd! - 'wykrzyknienie'; nagły wstyd; niezmierny wstyd; odrobina wstydu; palacy, piekacy wstyd; panieński wstyd; straszny wstyd; szalony wstyd; wstyd i hańba; wstyd komu 'ktoś się wstydzi'; wstyd przed kim / wobec kogo; wstyd za kogo, co.

Zwroty i frazy: coś jest wstydem dla kogoś; czuć wstyd za kogo; doznać wstydu / doznać uczucia wstydu; Jak ci nie wstyd? 'wstydź się'; jest mi / nam wstyd z jakiegoś powodu; kierować sięfatszywym wstydem; kłamanie bez wstydu; komuś jest wstyd przed kimś (kolegami, klasą, opinią); kończ waść, wstydu oszczędź 'prośba o zakończenie pojedynku, sporu'; najeść się wstydu 'doznać wiele wstydu, najczęściej z powodu niewłaściwego zachowania swojego lub bliskiej osoby’; natykać się wstydu 'doznać wielkiego wstydu'; narobić komu wstydu 'zawstydzić kogo', 'skompromitować kogo'; narobić sobie wstydu; nie mieć (za grosz) wstydu 'zachowywać się jak ktoś pozbawiony wstydu, ambicji, honoru, zachowywać się nieodpowiednio'; 'być bezczelnym'; nie móc podnieść oczu ze wstydu; oblać się rumieńcem wstydu; okryć się wstydem; oszczędzić komuś wstydu; palić się ze wstydu; płonać wstydem, ze wstydu; przynosić komu wstyd 'kompromitować kogo'; przyzwyczaić się do czegoś ze wstydem; pozbyć się wstydu; robić komu wstyd 'kompromitować kogo'; robi się komu wstyd 'ktoś zaczyna się wstydzić'; rumienić się, zarumienić się ze wstydu; rumieńce wstydu pala twarz; spalić się ze wstydu 'bardzo się wstydzić; tracić wstyd; twarz pali kogoś wstydem; uczucie wstydu ogarnia, powstrzymuje kogoś, onieśmiela; uczucie wstydu paraliżuje kogoś; umrzeć ze wstydu || umierać ze wstydu; wstyd bierze, ogarnia, zdejmuje kogo; wstyd dlawi, pali kogoś; wstyd mi swojej głupoty; wstyd mówić, wstyd powiedzieć, wstyd coś wyznać, robić, ogladać 
itp. 'odczuwam wstyd, jestem zawstydzony, skrępowany w związku z czymś'; wstyd nie pozwala zrobić czegos'; wstyd pali kogo; wstyd pali komuś czoło 'ktoś się bardzo wstydzi'; wstyd powstrzymuje kogo; wstydu nie mieć 'być pozbawionym honoru'; wystawiać kogo na wstyd 'narażać na urągowisko'; zapaść się pod ziemię ze wstydu; zapaść się pod ziemię ze wstydu; zrobić, robić komuś wstyd 'skompromitować, kompromitować kogoś, stać się, być powodem czyjegoś wstydu’21.

\section{f. przysłowia i sentencje}

Zgromadzone tu przysłowia są nie tylko esencją ludowej moralności, lecz także ukazują radykalizm etyczny dawnych epok ${ }^{22}$. Czego nie zabrania prawo, zabrania wstyd - 'o konieczności przestrzegania zasad przyzwoitości'; Gdyby się wszyscy ludzie swojego głupstwa wstydzili, widziatbyś każdego twarz wstydem zalana; Gdy niewiasta zdejmuje szate, zdejmuje też z siebie wstyd - 'nagość jest bezwstydna'; Gdzie nie ma wstydu, nie ma też honoru - 'zdolność odczuwania wstydu jest podstawą wszystkich innych cnót'; Gorszy wstyd niż boleść - 'poczucie wstydu niesie więcej cierpień niż ból fizyczny'; Kto nie ma wstydu, nie ma czci - 'zdolność odczuwania wstydu jest podstawą wszystkich innych cnót'; Kto raz miłego wstydu przekroczy granice, ten już znacznie będzie miat niewstydliwe lice; Lepiej z głodu umrzeć niż ze wstydu - 'nie należy wstydzić się ubóstwa'; Nic nędzniejszego jak wstyd swojego uczynku; Niewiasta, która wstyd traci, prędko się z niecnota braci (= brata); Ni wstydu, ni Boga; To żaden wstyd prosić o pomoc; Wstyd chtopa bardziej niż plaga boli; Wstyd dość raz utracić; Wstyd jest bojaźn gańby (hańby) (S. Petrycy); Wstyd jest pierwsza oznaka zepsucia, bezwstyd-ostatniq - 'uczucie wstydu świadczy o uświadomieniu sobie własnej niemoralności, a zatrata

${ }^{21}$ Materiał pochodzi z następujących słowników: Słstp, SPJKoch, L. SWil, SW, SzymSJP, DorSJP, PSWP, SWJP, ISJP, USJP, SSłfrazjp, SłfrazWP, WSfrazJP, WSfrazPWN.

${ }^{22}$ Materiał wyekscerpowany z następujących źródeł: Słsjp, SPJKoch, L. SWil, SW, SzymSJP, DorSJP, PSWP, ISJP, USJP, SSłfrazJP, SłfrazWP, WSfrazJP. 
tego uczucia o demoralizacji'; Wstyd jest tarcza cnoty - 'uczucie wstydu jest zabezpieczeniem przed niegodnymi czynami'; Wstyd nic innego nie jest, jeno jako stoikowie wykładaja, bojaźn złej sławy (Ł. Górnicki); Wstyd nie dym - w oczy nie gryzie - 'o zatraceniu poczucia wstydu'; Wstyd ostatnia niecnoty zapora; Wstyd, wstydliwość albo sromiężliwość uczciwa jest; Ze wstydu rad bym się pod ziemię schowat, zapadt.

\section{g. derywaty}

Formacje pokrewne wyrazowi wstyd to czasowniki: stpol., obecnie gwar. wstydać się (XVI w., L) 'odczuwać wstyd, wstydzić się', np. „Nie lękaj się ani nie wstydaj za upadek swój” (M. Rej, SW), „Drudzy się i swej kondycji i powołania wstydają" (P. Skarga, SW); wstydzić (się) (XVI w,, L) w zn.: 1) 'zawstydzać, wywoływać uczucie wstydu', np. „Mnie w tym wstydzą, iż lepiej niż ja trąbić umieją" (XVIII w., L), „Wstydził się i oczu podnieść nie mógł do góry” (W. Potocki, L); 2) 'okrywać wstydem, przynosić wstyd', np. „Uczciwa praca nie wstydzi nikogo" (SJP); 3) 'wstydzić się za kogo'; por. też formacje prefiksalne nawstydzić (się), powstydzić (się), zawstydzić (się); przymiotniki: wstydawy i niewstydawy (XVI w,, L) '(nie)związany ze wstydem', np. „Który cię ogień niewstydawy pali?”, (S. Petrycy, SW); wstydny (bezwstydny, niewstydny) (XVI w., L): 1) '(nie)zawstydzony, odczuwający wstyd', np. „Wstydna tej swojej słabości, jedną ręką twarz sobie zakryła” (XVIII w., L), „Dziewczęta (...) stłoczyły się w jednym kącie, zafrasowane i wstydne" (SJP); 2) 'wstyd przynoszący, kompromitujący’, np. „Przypomnieliśmy sobie Targowicę (...) wstydną słabość królewską" (XVIII w., SJP); por. też formacje pochodne: (nie)wstydność (XVIII w., L) '(nie)wstydliwość', np. „Niewstydność w mówieniu, plugawomowność” (L); wstydniś (XVIII w., L) 'skromniś, niewiniątko'; niewstydnik (XVIII w., L) 'człowiek bezwstydny'; niewstydnica (XVIII w., L) 'kobieta bezwstydna'; bezwstydnik (XVIII w., L) 'człowiek bezwstydny'; bezwstydnica 'kobieta bezwstydna'; (nie)wstydliwy (XVI w., L) w zn.: 1) '(nie)doznający łatwo uczucia wstydu', np. wstydliwy młodzian, 
wstydliwa panienka, 2) 'będący wyrazem zawstydzenia', np. wstydliwe spojrzenie, 3) 'przynoszący wstyd', np. choroby wstydliwe; por. pochodne: wstydliwość (XVIII w., L) 'nieśmiałość', np. „Wstydliwość jest przymiot wielce wyborny” (L), np. wstydliwość panieńska (SW); niewstydliwiec (XVIII w,, L) 'bezwstydnik'; rzeczowniki: niewstyd (XVIII w., L) 'brak wstydu', np. „Dziwowali się wszyscy niewstydowi tego człowieka" (SJP); bezwstyd (XVIII w., SJP) 'brak wstydu, nieskromność', np. „Niech mąż o twoim nic nie wie bezwstydzie!” (F. Zabłocki, SJP), „Żyłem w bezwstydzie, na kartach i pijatyce” (J. Słowacki, SJP).

Wyraz wstyd i pokrewne mu wstydzić (sie), wstydliwy, wstydliwość... stopniowo zastępują będące również dziedzictwem prsł. wyrazy srom, sromać się, sromotny, sromięźliwość... ${ }^{23}$

\section{WINA I WSTYD JAKO BRAK CNOTY MOR A LNEJ}

Kościół katolicki rozpatruje kwestie winy i wstydu w świetle cnót moralnych, głównie umiarkowania. Cnota moralna jest dobrą jakością umysłu ludzkiego mobilizującą go do życia zgodnie z uznanymi wartościami - do bycia prawym człowiekiem. W szerokim rozumieniu jest nie tylko stałym i dobrym usposobieniem człowieka, ale także stanem w praktyce przeżywanym; jest zdolnością do wykonywania dobrych czynów. Jak czytamy w Katechizmie Kościoła katolickiego: „Cnota jest habitualną i trwałą dyspozycją do czynienia dobra" (nr 1833). Wiąże się zatem z pewną umiejętnością słusznego działania i postępowania. Cnota nie jest czymś nabytym, ale wymaga ciągłego starania i pracy w doskonaleniu tej sprawności na co dzień. Wymaga ciągłego poszukiwania właściwej miary porządnego życia, czyli cnoty umiaru, którą Arystoteles nazywał regułą złotego środka. „(...) nadmiar jest błędem, niedostatek - przedmiotem nagany, środek zaś przedmiotem pochwał i czymś właściwym; jedno i drugie zaś jest związane nierozłącznie z dzielnością etyczną. Jest tedy dzielność,

${ }^{23}$ Por. K. D ł u g o s z - K u r c z a b o w a, Wielki słownik..., dz. cyt. 
etyczna pewnego rodzaju umiarem, skoro zmierza, do środka jako do swego celu"24. Dlatego pojawiające się uczucie winy i wstydu jest przede wszystkim konsekwencją zejścia z drogi cnoty umiarkowania.

Niepokój i poczucie winy towarzyszy ludzkiej świadomości w wypadku uzależnienia się od złych pragnień. Poczucie winy oraz wstyd pojawiają się wtedy, gdy człowiek nie jest w stanie zrezygnować z zawłaszczenia kolejnych niekoniecznych rzeczy. Zatem umiarkowanie jest cnotą moralną, która pozwala osiągnąc harmonię wewnętrzną i opanować nadmierną pożądliwość różnych dóbr, czy pragnienie doznawania ciągle nowych przyjemności (takich, które stają się głównym motywem działania) ${ }^{25}$. Dopiero po przekroczeniu dopuszczalnej granicy pojawia się refleksja prowadząca do uświadomienia sobie winy moralnej i wstydu, jednocześnie człowiek zaczyna zdawać sobie sprawę z tego, jak ważne jest samoograniczenie i powściągliwość.

\section{ROZUMIENIE WINY I WSTYDU W NAUCZANIU KOŚCIOLA KATOLICKIEGO}

Wina i wstyd często są związane z pojęciem grzechu pierworodnego. Już grzech Adama i Ewy wskazywał na ich pierworodną winę i zawstydzenie. „Pan Bóg zawołał na mężczyznę i zapytał go: Gdzie jesteś? On odpowiedział: Usłyszałem Twój głos w ogrodzie, przestraszyłem się, bo jestem nagi, i ukryłem się" (Rdz 3, 9-10). Zatem gdy pierwsi ludzie popełnili grzech niepostuszeństwa, zaczęli odczuwać wstyd (także z powodu nieposiadania ubrania) w odniesieniu do Boga, a nawet wobec siebie, musieli chować się przed Jahwe, lękając się Jego kary. Także ze poczuciem winy i wstydem opuszczali rajski ogród.

Podobnie opowiadanie biblijne o Kainie i Ablu rzuca pewne światło na związek grzechu z poczuciem winy moralnej, wyrzutami sumienia i przygnębienia. Po nieudanej próbie oszukania Boga (złożenie przez Kaina marnej ofiary) Kain chodził z opuszczoną

\footnotetext{
${ }^{24}$ A r y s t o t e le s, Etyka Nikomachejska, (tłum. D. Gromska), Warszawa 1982,

25 Por. KKK, nr 1809.
} s. 56. 
głową i posępną twarzą. „Dlaczego jesteś smutny i dlaczego twarz twoja jest ponura?" (Rdz 4, 6) - pytał Jahwe. Brak refleksji i poczucia winy z powodu uczynionego zła, a także zazdrość i złość za przyjętą ofiarę Abla przez Boga, doprowadziła Kaina do popełnienia kolejnego zła - grzechu bratobójstwa. „Wtedy Bóg zapytał Kaina: Gdzie jest brat twój Abel? On odpowiedział: Nie wiem. Czyż jestem stróżem brata mego?" (Rdz 4, 9). Należy zauważyć, że Kain nawet po zamordowaniu brata nie podjął skruchy i nawrócenia. Co więcejnie poczuwał się do odpowiedzialności za swój czyn, ale zagłuszył w sobie wstyd i poczucie winy, skazując się na hańbę, wygnanie i cierpienie w samotności. Wiadomo, że bez wyznania win nie ma pokuty, nawrócenia i poprawy. Jakże inną treść zawiera modlitwa zawstydzonego i pokornego starotestamentalnego grzesznika, obciążonego winą i błagającego Boga o litość. „Nie karć mnie, Panie, w swym gniewie, i nie karz w swej zapalczywości. Zmiłuj się nade mną, Panie, bom słaby" (Ps 6, 1-2).

Chociaż każdy człowiek rodzi się bez osobistej winy, to jednak, pomimo że grzechu sam jeszcze nie popełnił, przychodzi na świat z grzechem zaciagniętym, jak stwierdzono na Soborze Trydenckim ${ }^{26}$. Grzech pierworodny (zaciagnięty) jest zatem pewnym stanem, a nie aktem $^{27}$. „Cały rodzaj ludzki jest w Adamie sicut unum corpus unius hominis - jak jedno ciało jednego człowieka"28. Zatem pierwsi rodzice nie tylko utracili pierwotną świętość i sprawiedliwość, ale także przekazali ludzkości naturę człowieczą skażoną przez ich pierwszy grzech. Wówczas Bóg zapoczątkował historię zbawienia, posyłając swojego Syna na świat, aby dał nadzieję przytłoczonej ludzkości grzechem pierworodnym, który w końcu stał się szczęśliwa wina, gdyż odkupioną przez Jezusa Chrystusa ${ }^{29}$.

26 Por. Sobór Trydencki, DS 1511-1512. Jedynie Najświętsza Maryja, matka Zbawiciela Jezusa Chrystusa została zachowana od winy pierworodnej. Por. Sobór Watykański II, Konstytucja Lumen gentium, nr 59.

27 Por. KKK, nr 404.

28 KKK, nr 404.

29 Por. J a n P a w e 1 I I, Encyklika Redemtor hominis, nr 1. 
Kościół katolicki pomimo swojej sakramentalnej świętości ${ }^{30}$ doświadczał nie raz w ciągu wieków upadku moralnego, ale też poczucia winy i wstydu, zaciągniętego przez jego wiernych. „Istotnie (...) niemałe społeczności odłączyły się od pełnej wspólnoty z Kościołem katolickim, często nie bez winy ludzi z jednej i drugiej strony" 31 . Jednak „kto uświadamia sobie historię zbawienia i Wcielenia $\mathrm{z}$ ich wszystkimi konsekwencjami, ten nie gorszy się konkretnym historycznym kształtem Kościoła, który, jak mówi papież Franciszek, nie tylko promienieje blaskiem, ale jest także poturbowany" ${ }^{32}$. Zatem „dopiero z perspektywy wcielenia Logosu zrozumiała staje się dla nas" ${ }^{\prime 33}$ nauka Kościoła oparta na osobie Jezusa Chrystusa wzywającego zarówno do świętości jak i do ciągłego odnowienia i oczyszczenia ludzkości z winy i grzechu ${ }^{34}$.

W Katechizmie Kościoła Katolickiego kwestia wstydu i wstydliwości była analizowana między innymi w ramach dziewiątego przykazania ostrzegającego przed pożądaniem żony bliźniego swego (nr 2514-2527). Nawiązując do Soboru Trydenckiego, Katechizm zwrócił uwagę na ludzkie pożądanie, które „może oznaczać gwałtowną postać pragnienia ludzkiego. (...) Wywołuje ono nieporządek we władzach moralnych człowieka i nie będąc samo w sobie grzechem, skłania człowieka do popełnienia grzechów" (nr 2515). Pożądliwość ciała i oczu będzie zatem skłaniać człowieka do grzechu, a w konsekwencji do zaciągnięcia winy i wstydu. W Katechizmie podkreślono nieustanne napięcie w człowieku pomiędzy jego duchem

30 „Kościół jest święty, chociaż w swoim łonie obejmuje grzeszników, albowiem cieszy się nie innym życiem, jak życiem łaski; jeśli jego członki karmią się nią, uświęcają się, jeśli zaś odwracają się od niej, obciążają się grzechami i winami”" P a w e 1 V I, Wyznanie wiary Ludu Bożego, nr 19.

${ }_{31}$ Sobór Watykański II, dekret Unitatis redintegratio, nr 3.

${ }^{32}$ G. Mull e r, Benedykt XVI i Papież Franciszek. Ich postuga w sukcesji Piotrowej. Dziesięć lat Papieża Benedykta XVI, (tłum. S. Śledziewski), Warszawa 2015, s. 23 i 24.

33 Tamże, s. 22.

34 Por. Sobór Watykański II, Konstytucja dogmatyczna o Kościele Lumen gentium, nr 8. 
i ciałem, które mają różne dążenia. Dlatego trzeba opanowywać popędy ciała, aby nie ulec nieuporządkowanym pożądliwościom.

Postawa wstydu może się wiązać z naturalną nieśmiałością, skrytością, zażenowaniem, czy poczuciem niższości. Człowiek wstydzi się gdy zostanie negatywnie osądzony, gdy uświadamia sobie, że inni ludzie rozważają jego występek. Wstyd, wstydliwość nie zawsze musi być czymś złym, gdyż może chronić przed grzechem, czy prowadzić do nawrócenia. W Słowniku łacińsko-polskim czytamy, że termin łaciński verecundia ma znaczenie zarówno pozytywne jak i negatywne. Może być tłumaczony jako uczucie wstydu i hańby, ale także jako skromność, nieśmiałość czy obyczajnośćc ${ }^{35}$.

Stanisław Olejnik wyjaśnia, że wstyd jest czynnikiem obronnym zabezpieczającym daną osobę przed przedmiotowym użyciem, przede wszystkim w zakresie czystości seksualnej. Podkreśla, nawiązując do dokumentu kościelnego Persona humana, czyli Deklaracji o niektórych zagadnieniach etyki seksualnej z 1975 r. papieża Pawła VI, że wszelkie działania seksualne dotyczące życia płciowego powinny być podporządkowane prawdziwej miłości ${ }^{36}$. Wstyd może zatem wspomagać porządek moralny, który jest naruszany w wypadku odrywania miłości od sfery seksualnej. We wspomnianym dokumencie poruszono również problem aktów homoseksualizmu i jego związków z winą moralną. „W Piśmie Świętym są one potępione jako poważna deprawacja, a nawet są przedstawione jako zgubne następstwo odrzucenia Boga. Sąd ten nie uprawnia do stwierdzenia, że wszyscy dotknięci tą nieprawidłowością, mają tym samym winę osobistą; świadczy jednak, że akty homoseksualizmu są wewnętrznie nieuporządkowane i w żadnym przypadku nie mogą zostać zaaprobowane" ${ }^{37}$.

${ }_{35}$ Por. Słownik łacińsko-polski, (tłum. K. Kumaniecki), Warszawa 1981, s. 530.

${ }^{36}$ Por. S. O l e j n i k, Dar. Wezwanie. Odpowiedź. Moralność życia społecznego, Warszawa 1993, s. 80 i 81.

${ }^{37}$ Deklaracja o niektórych zagadnieniach etyki seksualnej Persona humana, nr 8 . 
W Katechizmie Kościoła Katolickiego znajdujemy stwierdzenie, że: „czystość domaga się wstydliwości. Jest ona integralną częścią umiarkowania. Wstydliwość chroni intymność osoby. Polega ona na odmowie odsłaniania tego, co powinno pozostać zakryte. (...) Wstydliwość strzeże tajemnicy osób i ich miłości" (2521 i 2522). Zatem wstydliwość jest cnotą umiarkowania, która może pełnić rolę chroniącą ludzką godność i tożsamość, może być przejawem pewnej skromności i dyskrecji. „Chrześcijanie (...) winni użyć zawsze zalecanych przez Kościół środków do prowadzenia czystego życia, jakimi są: karność zmysłów i ducha, czujność i roztropność w wystrzeganiu się okazji do grzechu, zachowanie wstydliwości i umiaru"38.

Według Katechizmu Rzymskiego: „Nie ma takiej winy, nawet najcięższej, której nie mógłby odpuścić Kościół święty. Nie ma nikogo tak niegodziwego i winnego, kto nie powinien być pewny przebaczenia, jeśli tylko jego żal jest szczery" (nr 11). Dzięki cnotom moralnym (kardynalnym i teologalnym) nabywamy trwałą dyspozycję do postępowania zgodnie z wolą Bożą, w konsekwencji unikając zaciągania winy i wstydu.

\section{ZAKOŃCZENIE}

Przeprowadzona analiza lingwistyczna miała na celu określenie miejsca leksemów wina i wstyd w systemie współczesnej polszczyzny. Aby ten cel osiągnąć, należało wskazać i opisać podstawowe kategorie językowe: pochodzenie (etymologię), znaczenie (semantyka), relacje $\mathrm{z}$ innymi jednostkami języka, procesy derywacyjne. Wina i wstyd to wyrazy obecne w polszczyźnie od samego początku, jako dziedzictwo języka prasłowiańskiego, a zarazem świadectwo wysokiego poziomu intelektualno-moralnego naszych przodków. Jako wyrazy rodzime mają mocną pozycję w systemie językowym. Semantyka wyrazów wina i wstyd została ukazana w dwu perspektywach: diachronicznej i synchronicznej. W odniesieniu do obu wyrazów ewolucja zmian przebiegała w kierunku od konkretu do abstraktu, przy czym

38 Tamże, nr 12. 
dawne znaczenia konkretne: wina 'grzywna, kara pieniężna' oraz wstyd 'narządy płciowe' w dobie nowopolskiej praktycznie już nie występują. W systemie języka narodowego wydzielamy tradycyjne słownictwo ogólne i słownictwo specjalistyczne, tzn. terminologię. Granica między tymi klasami jest nieostra. Widać to wyraźnie na przykładzie opisywanych leksemów, por. wina - to termin z zakresu prawa i etyki, a jednocześnie wyraz polszczyzny ogólnej. Bogactwo znaczeń i różnorodność odcieni semantycznych ujawniają ustabilizowane, trwałe związki wyrazowe, tzw. frazeologizmy (ze względu na typ łączliwości wydziela się połączenia imienne - tzw. wyrażenia, oraz połączenia werbalne - zwroty i frazy). Szczególna rola przypada przysłowiom i sentencjom, z których każde może być odczytywane jako skondensowana rozprawka o sensie głównego leksemu. Interesującą metodę opisu semantycznego danego leksemu jest zestawienie go z klasą wyrazów o podobnym (identycznym) znaczeniu. Zgromadzony tu materiał synonimów i wyrazów bliskoznacznych ukazuje bogactwo odcieni znaczeniowych opisywanych leksemów i ich udział we współtworzeniu różnych pól semantycznych. Pełniejszemu poznaniu sensu, treści znaczeniowych wyrazu służy nie tylko zestawienie go ze słowami o takim samym lub podobnym znaczeniu, ale także skonfrontowanie go z wyrazami o znaczeniu przeciwnym. Antonimy także pomagają w dotarciu do znaczenia wyrazu. Rozwój słownictwa dokonuje się przede wszystkim przez tworzenie nowych wyrazów od wyrazów już istniejących, czyli tzw. derywacja. O randze danego wyrazu w systemie językowym decyduje liczba formacji pochodnych: im więcej derywatów, tym mocniejsza jest jego pozycja w systemie. Okazuje się, że zarówno wina, jak i wstyd są produktywnymi bazami derywacyjnymi. Rekapitulując zatem powyższe rozważania, stwierdzamy, że wina i wstyd to wyrazy rodzime. Funkcjonują jako wyrazy polszczyzny ogólnej i jako terminy. Zajmują trwałe miejsce w systemie języka, o czym świadczą liczne związki wyrazowe oraz rozbudowana rodzina wyrazowa. Zaprezentowany tu materiał leksykalny umożliwi Czytelnikowi konfrontację własnej wiedzy o winie i wstydzie z przedstawionym tu językowym ich obrazem. 
Człowiek odpowiedzialny za swoje złe czyny ma poczucie winy i wstydu. Jeśli zrobi coś złego, nawet jeśli nikt o tym nie wie to doświadcza indywidualnego sądu, który uświadamia mu wewnętrzną winę. Zatem wina i wstyd wynikają z przekonania o odpowiedzialności moralnej. Człowiek pragnie w swoim postępowaniu zachować zgodność pomiędzy wartościami wyznawanymi, a realnymi uczynkami. Naruszenie systemu wartości prowadzi do przekonania o własnej winie, czego przejawami są: napięcie, żal i skrucha. Jednocześnie z poczucia winy człowiek może się uwolnić, w wypadku przyznania się, przeproszenia i naprawienia zła. Jak mówi Psalmista: „Nikt bowiem, kto Tobie ufa, nie doznaje wstydu; doznają wstydu ci, którzy łamią wiarę dla marności” (Ps 25, 3). Wstyd bardziej wiąże się z pewnymi emocjami wynikającymi z niskiej samooceny. Zawstydzona osoba czuje się obnażona, uświadamia sobie swoje braki i niekompetencje. Wstyd wywołuje uczucie bezsilności, ale także złość i agresję z powodu doznania przykrości i doświadczenia negatywnej oceny przez innych ludzi.

Kościół katolicki w swoim nauczaniu najczęściej kwestię winy i wstydu wiąże z grzechem i nieporządkiem moralnym. „Ale ponieważ często i ciężko grzeszyłem przeciw Tobie, słusznie powstaje przeciw mnie całe stworzenie, sprawiedliwie należy mi się wstyd i pogarda" 39 . Przede wszystkim zwraca uwagę na grzech nieposłuszeństwa i pychy będącego źródłem ludzkiej winy i zawstydzenia, a nawet wyrzutów sumienia. Jak mówi Psalmista: „Ja przecież wyznaję moją winę i trwożę się moim grzechem" (Ps 38, 19). Właściwie ukształtowane sumienie powinno ustrzec człowieka od fałszywego poczucia winy, a kierować ku wolności i pokoju serca ${ }^{40}$. Należy podkreślić, że Kościół katolicki w swoich rozważaniach więcej miejsca poświęca kwestii winy moralnej, aniżeli poczuciu wstydu czy wstydliwości.

\footnotetext{
39 T. Kempis, O naśladowaniu Chrystusa, dz. cyt., s. 71.

${ }^{40}$ Por. KKK, nr 1784 i 1785.
} 


\section{Streszczenie}

Przeprowadzona analiza lingwistyczna wykazała, że wina i wstyd to wyrazy odziedziczone z prajęzyka, o paralelnym rozwoju. Ich wspólną tendencją w zakresie semantyki było przechodzenie od konkretu do abstraktu i związany z tym zanik znaczeń konkretnych. Nieostra jest też granica między tymi wyrazami polszczyzny ogólnej a wyspecjalizowanymi terminami z dziedziny etyki. Oba wyrazy zajmują trwałe miejsce w systemie języka polskiego, o czym świadczą liczne związki wyrazowe, frazeologiczne, antonimiczne. Językowy obraz winy i wstydu zachęca do podejmowania próby indywidualnej jego interpretacji.

Kościół katolicki kwestię winy i wstydu wiąże z grzechem i nieporządkiem moralnym. Przede wszystkim zwraca uwagę na grzech nieposłuszeństwa i pychy będącego źródłem ludzkiej winy i zawstydzenia, a nawet wyrzutów sumienia. Zaleca umiarkowanie, które jest cnotą moralną, pozwalającą osiągnąć harmonię wewnętrzną i uniknąć winy i wstydu.

\section{The issue of guilt and shame in view of the teaching of the Catholic Church. Analysis of linguistic and moral. Summary}

Linguistic analysis carried out showed that the guilt and shame are words inherited from proto-language, about the parallel development. Their common trend in the field of semantics was the transition from the concrete to the abstract and the consequent disappearance of meanings specific. It is also blurred the boundary between these words of Polish general and specialized terms in the field of ethics. Both words occupy a permanent place in the Polish language system, as evidenced by numerous relationships of expression, phraseology, antonymic. Linguistic picture of guilt and shame encourages individual attempts to interpret it.

The Catholic Church issue of guilt and shame associated with sin and moral disorder. First of all, it draws attention to the sin of disobedience and pride as a source of human guilt and shame and even guilt. We recommend moderation, which is a moral virtue, to achieve harmony allowing internal and avoid guilt and shame.

Słowa klucze: wina, poczucie winy, wina moralna, wstyd, wstydliwość, analiza lingwistyczna

Key words: fault, feeling guilty, moral guilt, shame, modesty, analysis of linguistic 
Nota o autorach: dr Krystyna Długosz-Kurczabowa (1940-2016) - filolog, doktor nauk humanistycznych w zakresie językoznawstwa. Zajmowała się gramatyką historyczną języka polskiego, polskim językiem religijnym, translatoryką biblijną. Pracowała w Instytucie Filologii na Wydziale Polonistyki Uniwersytetu Warszawskiego. Ks. prof. UKSW dr hab. Krzysztof Kietliński - teolog moralista, podejmujący problematykę gospodarczo-społeczną, zwłaszcza w teoretycznym wymiarze uzasadnień moralnego wymiaru życia ekonomicznego. Pracuje na Wydziela Teologicznym UKSW w Warszawie.

\section{Bibliografia}

Arystoteles, Etyka Nikomachejska, tłum. D. Gromska, Warszawa 1982.

Bańka M. (red.), Inny słownik języka polskiego, Warszawa 2000.

Bąba S., Liberek J., Słownik frazeologiczny współczesnej polszczyzny, Warszawa 2001

Boryś W., Słownik etymologiczny języka polskiego, Kraków 2005.

Dąbrówka A., Geller E., Słownik antonimów, Warszawa 1995.

Dąbrówka A., Geller E., Turczyn R., Słownik synonimów, Warszawa 1993.

Deklaracja o niektórych zagadnieniach etyki seksualnej Persona humana, http:// www.nonpossumus.pl/encykliki/KWC/persona_humana/

Długosz-Kurczabowa K., Wielki słownik etymologiczno-historyczny języka polskiego, Warszawa 2008.

Doroszewski W. (red.), Słownik języka polskiego, t. 1-11, Warszawa 1958-1969.

Dubisz S. (red.), Uniwersalny słownik języka polskiego, t. 1-6, Warszawa 2003.

Dunaj B. (red.), Słownik współczesnego języka polskiego, Warszawa 1996.

Jan Paweł II, Adhortacja Apostolska Reconciliatio et paenitentia, Poznań 1985.

Jan Paweł II, Encyklika Redemtor hominis, Kraków 1980.

Katechizm Kościoła Katolickiego, Poznań 1994.

Katechizm Rzymski wedtug uchwaty św. Soboru Trydenckiego, Kraków 1880.

Kempis T., O naśladowaniu Jezusa Chrystusa, tłum. A. Kamieńska, Warszawa 1981.

Kłosińska A., Sobol E., Stankiewicz A. (red.), Wielki słownik frazeologiczny PWN z przystowiami, Warszawa 2005.

Linde S. B., Słownik języka polskiego, t. I-VI, Warszawa 1807-1815, wyd. II, Lwów 1854-1860.

Muller G., Benedykt XVI i Papież Franciszek. Ich posługa w sukcesji Piotrowej. Dziesięć lat Papieża Benedykta XVI, tłum. S. Śledziewski, Warszawa 2015. 
Olejnik S., Dar. Wezwanie. Odpowiedź. Moralność życia społecznego, Warszawa 1993.

Skorupka S., Słownik frazeologiczny języka polskiego, t. I-II, Warszawa 1967.

Skorupka S., Stownik wyrazów bliskoznacznych, Warszawa 1971.

Karłowicz J., Kryński A., Niedźwiecki W. (red.), Słownik języka polskiego, t. I-VIII, Warszawa 1900-1927.

Kucała M. (red.), Stownik polszczyzny Jana Kochanowskiego, t. I-V, Kraków 2012. Szymczak M. (red.), Słownik języka polskiego, t. I-III, Warszawa 1978-1981.

Słownik języka polskiego, wyd. staraniem M. Orgelbranda, t. 1-2, Wilno 1961.

Stownik tacińsko-polski, tłum. K. Kumaniecki, Warszawa 1981.

Urbańczyk S. (red.), Encyklopedia wiedzy o języku polskim, Wrocław-Warszawa-Kraków-Gdańsk 1978.

Urbańczyk S. (red.), Słownik staropolski PAN, t. I-XI, Wrocław-Kraków-Warszawa 1953-1999.

Sobór Watykański II, Kostytucje - Dekrety - Deklaracje, Poznań 2002.

Zawiliński R., Dobór wyrazów, Słownik wyrazów bliskoznacznych i jednoznacznych, Kraków 1926.

Zgółkowa H. (red.), Praktyczny słownik współczesnej polszczyzny, t. 1-50, Poznań 2004. 